Article

\title{
In Situ Trace Elemental Analyses of Scheelite from the Chuankou Deposit, South China: Implications for Ore Genesis
}

\author{
Junqing Pan ${ }^{1,2}$, Tagen Dai ${ }^{1,2}$, Dexian Zhang ${ }^{1,2, *} \mathbb{C}$, Wenshen $\mathrm{Li}^{3}$, Richard C. Bayless ${ }^{1,2}$ and \\ Jianfeng Gao 4 (D) \\ 1 School of Geosciences and Info-Physics, Central South University, Changsha 410083, China; \\ pjqcsu@163.com (J.P.); dtg@csu.edu.cn (T.D.); richardbayless@protonmail.com (R.C.B.) \\ 2 Key Laboratory of Metallogenic Prediction of Nonferrous Metals and Geological Environment Monitor, \\ Central South University, Ministry of Education, Changsha 410083, China \\ 3 State Key Laboratory for Mineral Deposits Research, Institute of Geo-Fluids, School of Earth Sciences and \\ Engineering, Nanjing University, Nanjing 210023, China; lws3611@163.com \\ 4 State Key Laboratory of Ore Deposit Geochemistry, Institute of Geochemistry, Chinese Academy of Sciences, \\ Guiyang 550081, China; Gaojianfeng@mail.gyig.ac.cn \\ * Correspondence: dexian.zhang@csu.edu.cn
}

Received: 3 September 2020; Accepted: 9 November 2020; Published: 12 November 2020

\begin{abstract}
The Chuankou tungsten ore field is situated in the central area of the Xuefeng Uplift Belt in South China. The deposit is characterized by two types of tungsten mineralization: quartz-scheelite veins in both the Neoproterozoic Banxi Group and Devonian Yanglin'ao Formation and quartz-wolframite (scheelite) veins in the Chuankou granite. The host rocks of the Chuankou tungsten Deposit of South China are similar to the stratigraphic sequence of Au-Sb-W deposits in the Xuefeng Uplift Belt. It is thus an appropriate location for the study of scheelite mineralization in the belt, especially the relative contributions of surrounding rocks, magma and hydrothermal fluids. Optical Microscope-Cathodoluminescene (OM-CL) and Laser Ablation Inductively Coupled Mass Spectrometers (LA ICPMS) were used to examine scheelite textures and trace element concentrations in the Chuankou deposits. Scheelite in quartz-scheelite veins was formed over three generations. In situ LA-ICPMS trace elemental analyses of scheelite I show light rare earth element (LREE)-rich REE patterns and negative Eu anomalies, suggesting a relatively close fluid system. Significantly positive $\mathrm{Eu}$ anomalies of scheelite II and III indicate variable degrees of addition of meteoric water during scheelite precipitation. Therefore, ore-forming fluids of the Chuankou deposit were dominantly magma-derived, with different contributions of recycled meteoric water in the surrounding strata.
\end{abstract}

Keywords: scheelite; trace element chemistry; REE patterns; OM-CL; LA ICPMS

\section{Introduction}

Scheelite is one of the most common ore minerals in the tungsten deposit. Scheelite has a molecular formula $\mathrm{CaWO}_{4}$. Scheelite crystals have tetrahedral symmetry $\left(\mathrm{WO}_{4}\right)^{2-}$ and irregular dodecahedra $\left[\mathrm{CaO}_{8}\right]_{14}$, in which $\mathrm{W}^{6+}$ and $\mathrm{Ca}^{2+}$ are found in octagonal coordination. Due to its internal crystal structure, scheelite contains many trace elements such as $\mathrm{Sr}, \mathrm{Ba}, \mathrm{Nb}, \mathrm{Ta}, \mathrm{REE}, \mathrm{Mo}, \mathrm{Pb}$, Th and $\mathrm{U}$ which replace $\mathrm{W}^{6+}$ and $\mathrm{Ca}^{2+}$ by solid solution [1-6]. The substitution mechanisms in scheelite have been widely studied [1,3-5,7-11]. The REE distribution patterns and total REE concentrations in scheelite play an important role for investigating their precipitation processes and ore-forming mechanisms. Europium anomalies were identified in many deposits and can be used to indicate the temperature of scheelite crystallization, the substitution mechanism and the Na activity during 
scheelite crystallization [12]. Anomalies in Eu values $(\delta \mathrm{Eu})$ can also reflect the degree of magma differentiation, and are also closely related to $\mathrm{pH}$ value $[2,4,11,13-15]$. Cathodoluminescene (CL) imaging has proved to be an effective technique for revealing internal texture, zoning and trace element distribution in scheelite $[1,2,14,16,17]$, since the crystal structure is the primary control of $\mathrm{CL}$ intensity. The addition of trace elements changes the structure of scheelite, thus affecting the intensity of luminescence. At present, CL imaging can be acquired by coupling an optical microscope and a CL detector (OM-CL) as well as by coupling a scanning electron microprobe (SEM) with a CL detector (SEM-CL) $[1,2,8,14,16,17]$. OM-CL is relatively inexpensive and in situ observation equipment allows real time field investigation of precipitation history of scheelite by texture [18]. In contrast, laser ablation inductively coupled mass spectrometers (LA-ICP-MS) have been widely used for in situ analyses of trace element components and to investigate the elemental compositions and distribution in various minerals, including scheelite $[7,8,10,14,19,20]$.

Tungsten deposits in South China account for $80 \%$ of China's tungsten resources [9,10,21-24]. Most of the tungsten deposit in the south east of South China have a special element association of W-Sn and are closely associated with the intrusion. Meanwhile, tungsten mineralization of the Xuefeng Uplift Belt in the northwest of South China has Au-Sb-W element associations and is hosted in the Neoproterozoic Banxi Group. The Chuankou tungsten deposit is an important deposit in South China. Two types of tungsten mineralization have developed in the deposit, quartz-scheelite veins in sandstone and slate of the Neoproterozoic Banxi Group and the quartz-sandstone of the Devonian Yanlin'ao Formation as well as quartz-wolframite (scheelite)-bearing veins in the Chuankou granite [24]. The scheelite mineralization in the Chuankou deposit is found primarily in the slate of the Neoproterozoic Banxi Group and the Devonian Yanlin'ao Formation, showing a stratigraphic sequence similar to the Au-Sb-W deposits in the Xuefeng Uplift Belt, such as the Woxi Au-Sb-W Deposit and the Zhazixi Sb-W Deposit [25], and also close to the Chuankou granite. Previous studies have been conducted on the ore geology and petrogenesis of ore-related granite, but the evolution of the ore-forming fluids and the ore-forming process has still not been addressed well.

In this study, we use an optical microscope, OM-CL and in situ LA-ICP-MS analyses to investigate trace element compositions and distribution in scheelite from the Chuankou tungsten deposit. We compare the trace element compositions of scheelite of Chuankou with those of other types of tungsten deposits in China (including pegmatite-type Xuebaoding deposit in Sichuan Province, quartz-vein type Xingluokeng deposit in Fujian Province and skarn-type Shizhuyuan W-Sn-Bi-Wo deposit in Hunan Province) to further understand the process and conditions of the ore-forming system at Chuankou. This study set out to (1) determine the origin of the ore-forming elements such as $\mathrm{Ca}^{2+}$, (2) compare the nature and evolution of ore-forming fluids between the Chuankou deposit and $\mathrm{Au}-\mathrm{Sb}-\mathrm{W}$ deposits in the Xuefeng Uplift Belt and other deposits in South China and (3) summarize the regional tungsten mineralization types.

\section{Geologic Settings}

\subsection{Regional Geology}

The South China Block (SCB) is separated from the North China Block by the Qinling Belt. It is subdivided into two parts [9,21]: The Cathaysia Block to the southeast and the Yangtze Craton to the northwest $[21,24,26,27]$, which is separated by the Jiangnan Orogenic Belt consisting of the Xuefeng Uplift Belt (XUB) and the Middle to Lower Yangtze River Belt (MLYRB). The major stratigraphic sequences in XUB are the Neoproterozoic Lengiaxi and Banxi groups, which are composed of metasedimentary rocks, a turbiditic sequence of greywacke, siltstone and slate. Numerous Au-Sb-W deposits were identified in XUB, such as the Woxi Au-Sb-W deposit, Zhazixi Sb-W deposit and Cangziping Au-W deposit in Hunan Province [21,24,26,28-32]. Unique element associations of $\mathrm{Au}$, $\mathrm{Sb}$ and $\mathrm{W}$ suggested that these deposits are formed from a low-temperature hydrothermal system. In contrast, most tungsten deposits in the Cathaysia Block [27,33], e.g., the Zhuxi skarn-type scheelite 
deposit in Jiangxi Province, the Yaoling tungsten deposit in Guangdong Province, the Yaoganxian tungsten deposit and the giant Shizhuyuan W-Sn-Mo-Bi deposit in southern Hunan Province, and the Xingluokeng tungsten deposit in Fujian Province, are intimately associated with intrusions (Figure 1), suggesting the formation of a medium to high-temperature hydrothermal system. The Xuebaoding W-Sn-Be deposit is a pegmatite-type deposit in the Songpan-Garze poly-metallic belt in Sichuan Province [34-36].

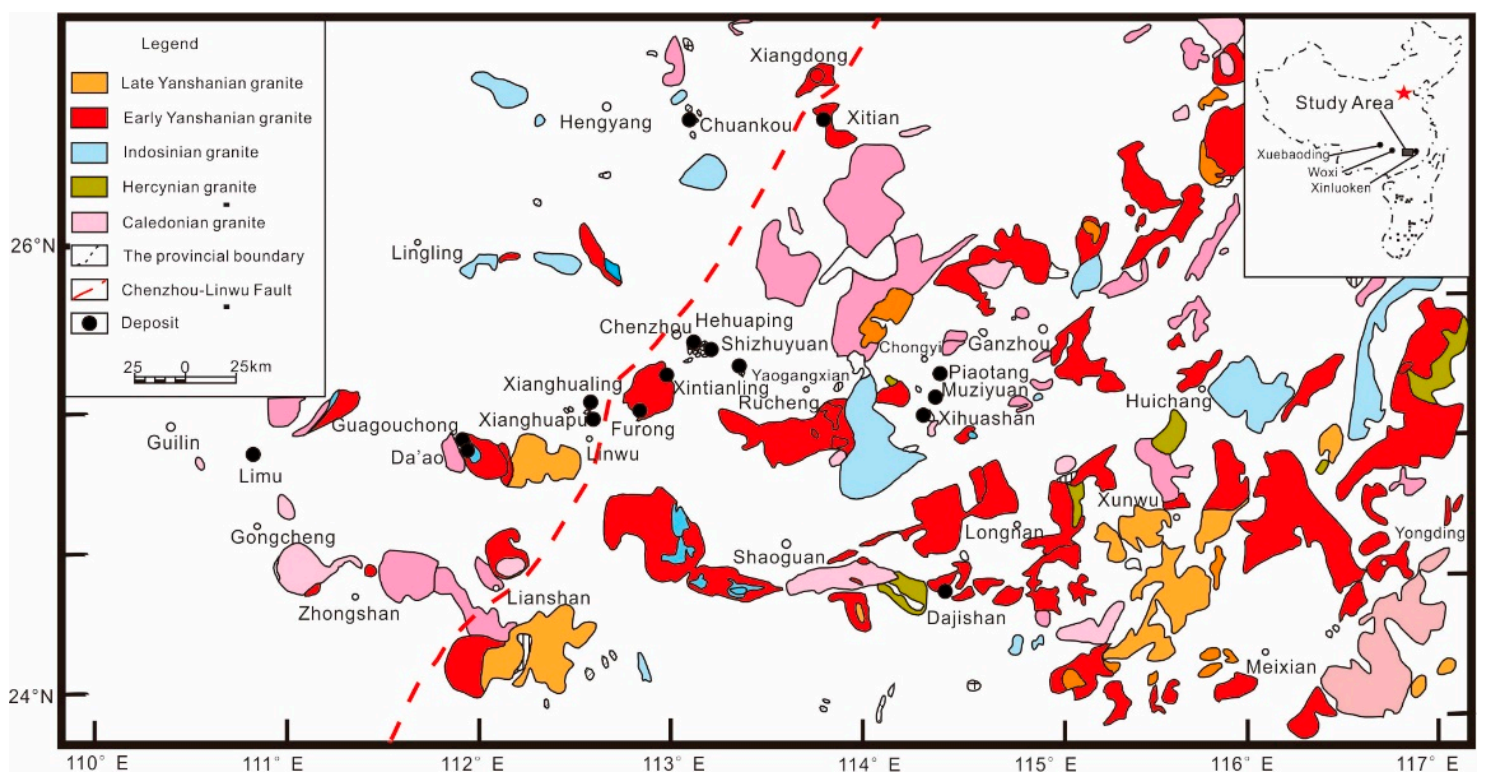

Figure 1. Sketch geological map of the Chuankou tungsten deposit (modified after [27]) showing the location of the Chuankou tungsten deposit and some important intrusion-related tungsten deposits in South China, such as the Limu tungsten deposit in Guangxi Province; Guagouchong, Da'ao, Xianghuapu, Xianghualing, Furong, Xintiangling, Shizhuyuan, Hehuaping W deposit in Hunan Province; Dajishan W deposit in Guangdong Province; and the Xihuashan, Muziyuan, Piaotang W deposits in Jianxi Province. Note, most deposits are associated with granite intrusions.

\subsection{Ore Deposit Geology}

The Chuankou tungsten deposit is an important fraction of tungsten resources in South China with resources of $11.1 \mathrm{Mt}$ with an average grade of $0.5 \% \mathrm{WO}_{3}$ [37]. It consists of the Yanglin'ao, Yaomuling, Chishui and Sanjiaotang ore segments, with present mining focused on the Yanglin'ao ore segment (Figure 2A-C). The scheelite mineralization is hosted in slate, sandstone and siltstones of the Neoproterozoic Banxi Group and Devonian Yanglin'ao Formation at the Yanglin'ao ore segment.

There are more than 30 intrusions in the Chuankou region [37], all of which have the same origin but were intruded in different stages. Three types of intrusive rock were identified based on mineral components: muscovite granite, two mica granite and biotite granite. The three granites extend in concentric ring form around the centers of the intrusions, with the muscovite granite farthest from intrusions and the biotite granite adjacent to intrusions and each other in gradual transition.

Faults are well developed in the mining area, mainly consisting of two groups, North North West (NNW) and North East (NE) trending. Scheelite mineralization is closely related to NNW trending faults. Granite is exposed in the east part of the mining area and it extends to about a $400 \mathrm{~m}$ depth with an angle of 60-70 degrees in the NNW direction, and then extends to the deep part of the mining area at an angle of about 25 degrees (Figure 2B). The Chuankou tungsten deposit lies in a limb of a NW-SE trending anticline which has many well-developed NW-SE trending faults. The $\mathrm{F}_{24}$ Fault, in the contact between the Neoproterozoic Banxi Group slate and the Chuankou granite, is a compressional shear fault formed before mineralization, and acts as a normal fault during tungsten mineralization. To the 
west of the $\mathrm{F}_{24}$ Fault, scheelite is the dominant ore, while to the east of the fault the ore mineral is predominately wolframite in granite (Figure 2C).

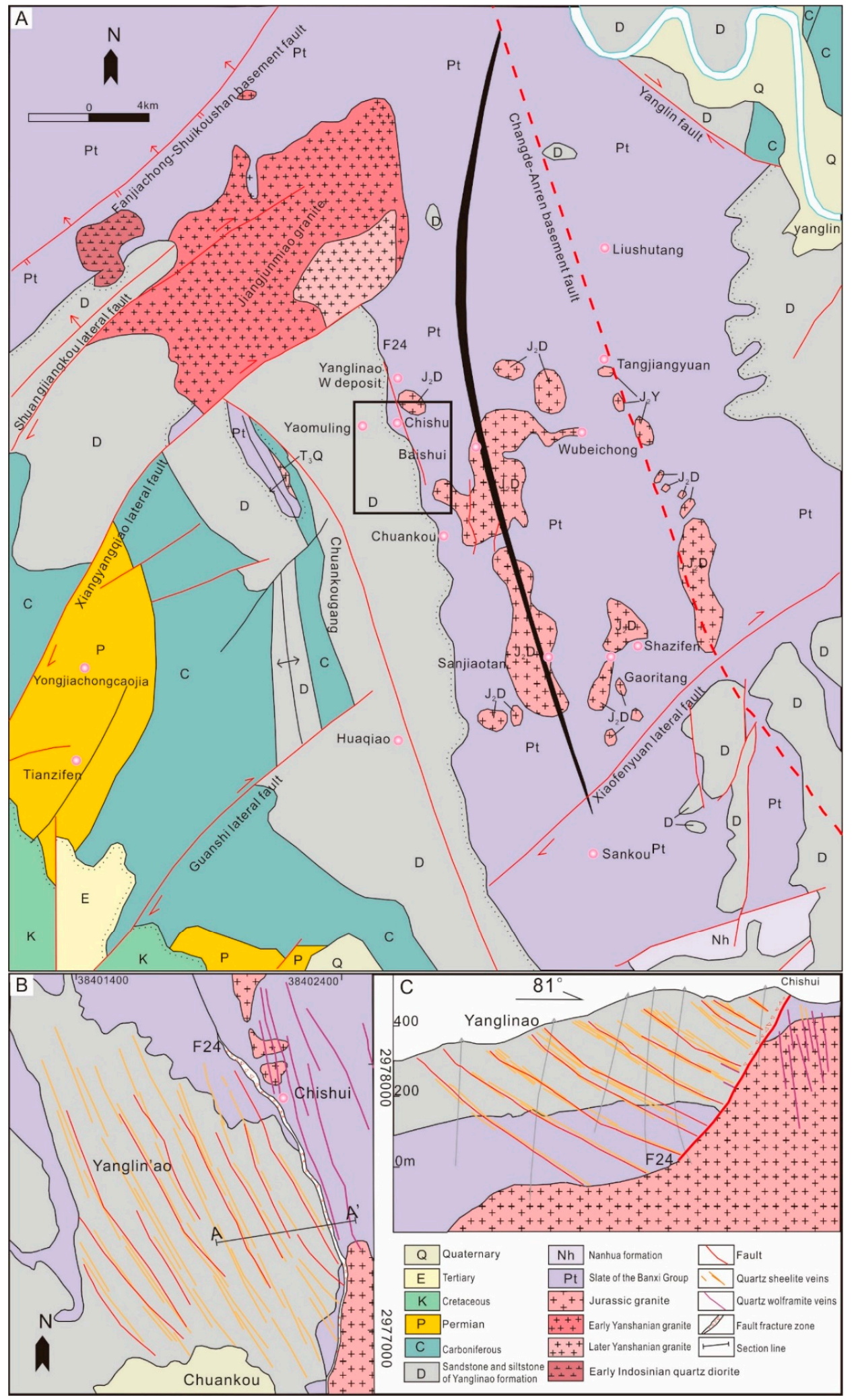

Figure 2. (A) Location of Chuankou tungsten deposit; and (B) sketch geological map, and (C) cross section of the Yanglin'ao ore segment. (modified after the Hengyang Yuanjing tungsten Mining CO., LTD, unpublished geological report, 2012). 
The tungsten orebody in the Yanglin'ao ore segment is mainly hosted in the sandstone of Devonian Yanglin'ao Formation and the slate of Neoproterozoic Banxi Group. It occurs as disseminated and quartz-scheelite veins (Figure 3A-D). The scheelite orebody is strictly controlled by a NNW trending fault. The mineralization intensity increases toward the granite. The scheelite orebody plunges SE to depth. More than 55 veins are distributed in an area ranging $1300 \mathrm{~m}$ in length and $500 \mathrm{~m}$ in width. The major ore minerals are scheelite with minor pyrite, chalcopyrite, molybdenite, arsenopyrite, magnetite, hematite, cassiterite and wolframite. The gangue minerals are quartz, muscovite, sericite and minor feldspar, calcite, chlorite, apatite, tourmaline and zircon.
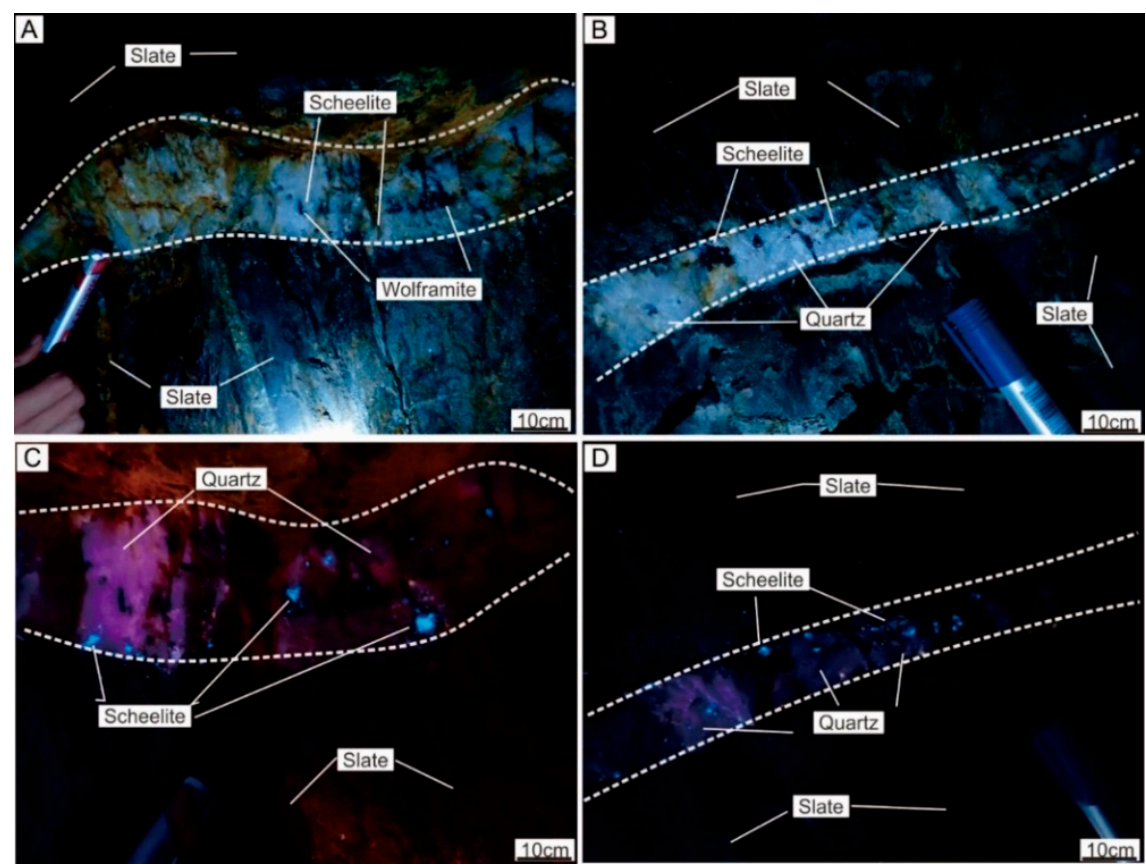

Figure 3. Outcrop photo of quartz-scheelite veins and disseminated scheelite in the tunnel at the Chuankou tungsten deposit; (A,B) show the occurrence of quartz-scheelite veins; (C,D) scheelite under a hand pick UV light, showing occurrence of scheelite in the same veins as $(\mathbf{A}, \mathbf{B})$.

\section{Materials and Methods}

A large number of field geological surveys in the Chuankou tungsten deposit, yielded more than 50 representative scheelite samples from mining tunnels at different elevations. Fifteen samples from the quartz-scheelite veins in the Yanglin'ao ore segment were selected for in situ LA-ICP-MS analysis. Two samples from the Xingluokeng tungsten deposit, one sample from the Xuebaoding W-Sn-Be deposit, five samples from the Shizhuyuan W-Sn-Bi-Mo deposit and two samples from the Woxi Au-Sb-W deposit were also included for comparison. The twenty-five scheelite samples were sliced to make double polished thick sections $(120 \mu \mathrm{m})$, then detailed observations and analyses were conducted on these samples as follows.

\subsection{Optical Microscopy and OM-CL}

A hand pick UV light was used to quickly and easily identify the position and distribution of scheelite in the double polished thick sections and they were marked. Then, a Zeiss A1 microscope was employed to determine the texture of scheelite in thin sections and thick sections $(120 \mu \mathrm{m})$ and these images were combined with the CL textures (Figures 4 and 5). Finally, they were examined using a Zeiss A1 microscope coupled with a CFL-II Cathodoluminescene detector at the Key Laboratory of Metallogenic Prediction of Nonferrous Metals and Geological Environment Monitor, Ministry of Education, at the Central South University, Changsha, Hunan Province. The typical voltage ranges were from 6 to $15 \mathrm{KV}$, and the current ranged from 220 to $380 \mu \mathrm{A}$. 

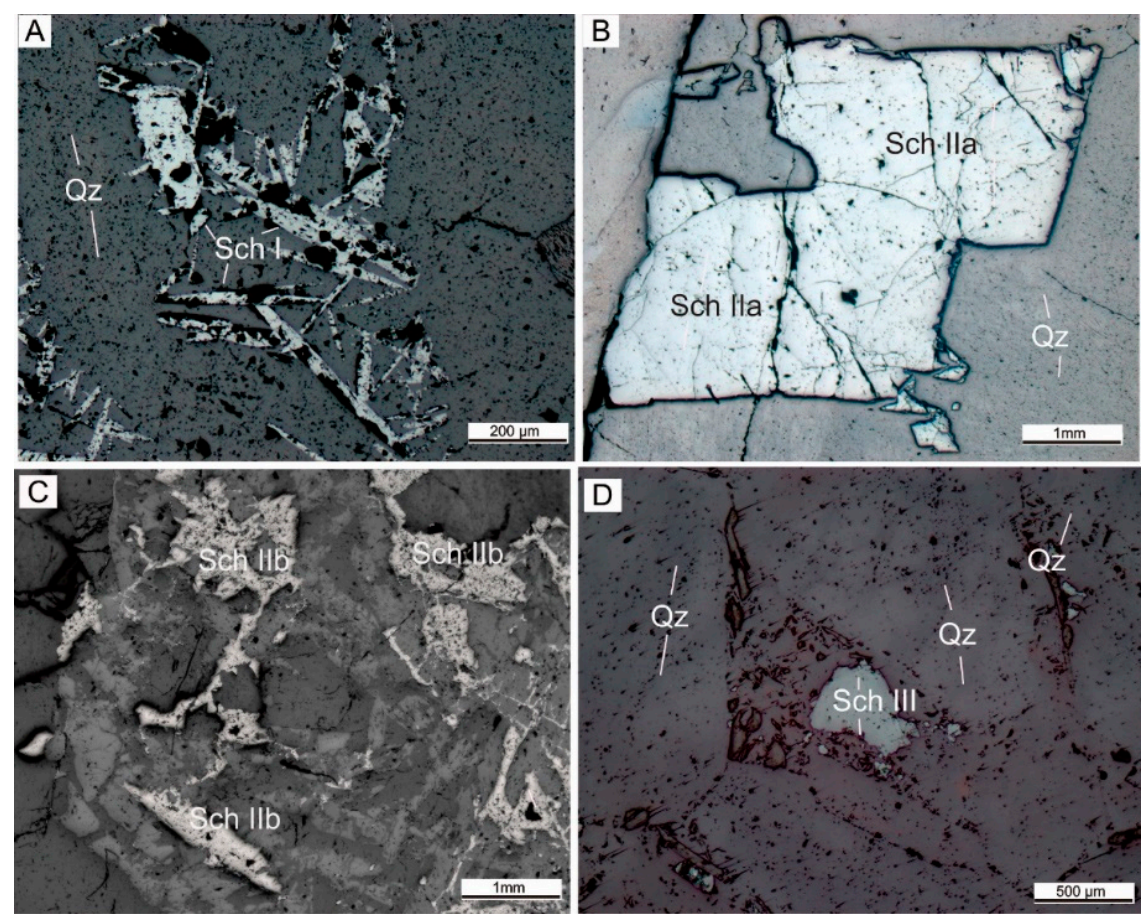

Figure 4. Typical ore texture under microscopy showing scheelite from the Chuankou tungsten deposit. (A). Wolframite partly replaced by scheelite; (B). Coarse grain Euhedra scheelite grain; (C). Wolframite replaced by scheelite along the edge of wolframite; (D) Disseminated scheelite distributed in the quartz matrix. Abbreviation: Sch-scheelite; Qz-quartz.
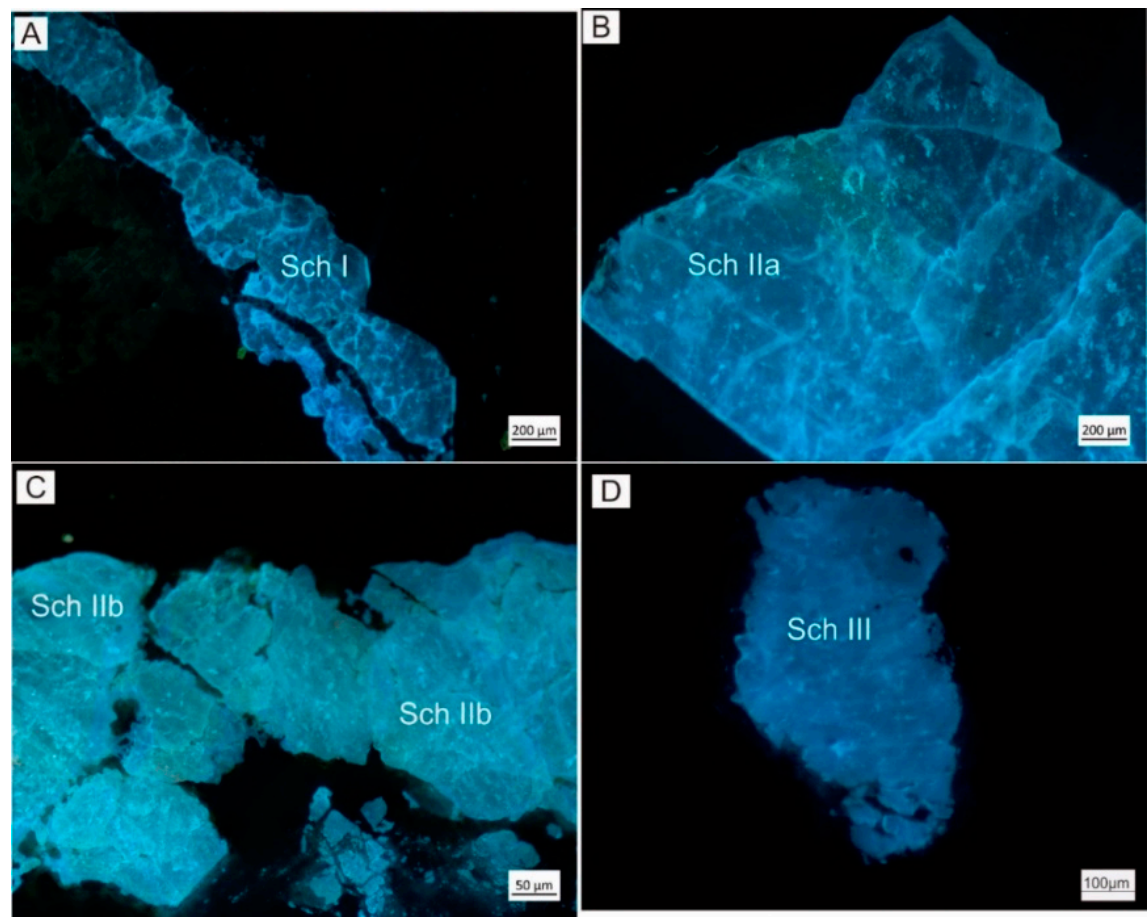

Figure 5. Microphotos under optical-microscopy and coupled cathodoluminescene. (A) Anhedral fine grain scheelite replacing wolframite in the tunsten mineralization veins; (B) Sub-euhedral coarse grain scheelite from the quartz-scheelite veins in the slate; (C) Sub-euhedral coarse grain scheelite and fractured scheelite from the quartz-scheelite vien in the slate, typical hydrothermal fluids altered the scheelite along the edge of scheelite; (D) Anhedral coarse grain scheelite from the quartz-sheelite veins in the sandstones. Abbreviation: Sch-scheelite. 


\subsection{LA-ICP-MS Analyses}

In situ trace element compositions of individual scheelite grains were measured using a Teledyne Photon Machines Analyte He Excimer 193 nm laser ablation system, coupled to an Analytik Jena Plasma Quant MS Ellite ICPMS at the Key Laboratory of Metallogenic Prediction of Nonferrous Metals and Geological Environment Monitor of Ministry of Education, Central South University, Changsha, Hunan Province. The selected thin/thick sections were cleaned and placed into the HelEx II chamfer cell of the laser. The samples were placed in a sealed ablation cell that was constantly flushed with a mixture of high purity $\operatorname{Ar}(13.5 \mathrm{~L} / \mathrm{min})$ and He gases $(1.1 \mathrm{~L} / \mathrm{min})$. Spot sizes were $35 \sim 50 \mu \mathrm{m}$. The laser repetition rate was typically $5 \mathrm{~Hz}$ and laser beam energy at the sample was maintained around $2.0 \mathrm{~J} / \mathrm{cm}^{2}$. The analyze time for each spot was $70 \mathrm{~s}$, comprising a $20 \mathrm{~s}$ measurement of background (laser off) and a $30 \mathrm{~s}$ analyzes signal and $20 \mathrm{~s}$ washout time. The measured elements include ${ }^{23} \mathrm{Na},{ }^{25} \mathrm{Mg},{ }^{29} \mathrm{Si}$, ${ }^{43} \mathrm{Ca},{ }^{45} \mathrm{Sc},{ }^{49} \mathrm{Ti},{ }^{55} \mathrm{Mn},{ }^{57} \mathrm{Fe},{ }^{65} \mathrm{Cu},{ }^{66} \mathrm{Zn},{ }^{75} \mathrm{As},{ }^{85} \mathrm{Rb},{ }^{88} \mathrm{Sr},{ }^{89} \mathrm{Y},{ }^{91} \mathrm{Zr},{ }^{93} \mathrm{Nb},{ }^{98} \mathrm{Mo},{ }^{118} \mathrm{Sn},{ }^{137} \mathrm{Ba},{ }^{139} \mathrm{La},{ }^{140} \mathrm{Ce}$, ${ }^{141} \mathrm{Pr},{ }^{143} \mathrm{Nd},{ }^{147} \mathrm{Sm}, 1^{53} \mathrm{Eu},{ }^{157} \mathrm{Gd},{ }^{159} \mathrm{~Tb},{ }^{163} \mathrm{Dy},{ }^{165} \mathrm{Ho},{ }^{167} \mathrm{Er},{ }^{169} \mathrm{Tm},{ }^{171} \mathrm{Yb},{ }^{178} \mathrm{Hf},{ }^{181} \mathrm{Ta},{ }^{182} \mathrm{~W},{ }^{208} \mathrm{~Pb}$, ${ }^{209} \mathrm{Bi},{ }^{232} \mathrm{Th}$ and ${ }^{238} \mathrm{U}$.

The geochemical reference material NIST SRM 610 and USGS GSE-1G were used as external standards for scheelite analyses, and Ca was the internal standard. In addition, NIST SRM 610 was used as the system monitoring sample. USGS geochemical reference materials BCR-2G, BHVO-2G and BIR-2G were used for quality control. Data reductions relied on GLITTER 4.4.4 developed by GEMOC and were performed according to standard methods [38]. All results for all measured trace elements were in good agreement with published standard materials. When calculating the $(\mathrm{Eu})_{\mathrm{N}}{ }^{*}$, we use $(\mathrm{Eu})_{\mathrm{N}}^{*}=$ square $(\mathrm{Sm}+\mathrm{Nd})_{\mathrm{N}}$.

\section{Results}

Detailed scheelite texture both under microscopy and OM-CL are shown in Figure 4A-D and Figure 5A-D, respectively. A total of 274 scheelite spots on 25 samples were analyzed, and trace element concentrations were obtained by LA-ICPMS and are described in Supplementary Table S1. REE patterns of samples are present in Figures 7 and 8.

\subsection{Optical Microscopy and $O M-C L$}

CL imaging indicated that individual scheelite crystals are not zoned with respect to trace element distribution (Figure 5). Therefore, small laser spot analyses could be used to characterize entire scheelite grains. Based on the elevation, $\mathrm{CL}$ textures and characteristics observed under the microscope, three generations of scheelite (I, II, III) in the Chuankou tungsten deposit were identified. Scheelite I was generally collected from quartz-scheelite veins close to the granite, which locally coexists with wolframite. Scheelite from this location maintained the shape of wolframite (Figure 4A), which is acicular with a length of 300 500 $\mu \mathrm{m}$. The CL imaging shows fine grain scheelite aggregate in the veins with a dark-blue $C L$ response in the most of the scheelite individual grains, but a bright-blue CL response along the edge of each scheelite grain (Figure 5A).

Scheelite II samples were collected from the quartz-scheelite veins located in slate close to the granite. Scheelite II was subdivided into two sub types: Scheelite IIa and IIb according to occurrence and geological characteristics. Scheelite IIa is coarse grained (more than $0.5 \mathrm{~mm}$ ) and is euhedral (Figure 4B). This type of scheelite has a bright to dark-green CL response and does not have any oscillatory zone within the scheelite grains (Figure 5B). Scheelite Ilb crystals are irregular, silky and found distributed along the edges of quartz and garnet (Figure 4C). Scheelite IIb has green to dark blue CL response (Figure 5C), and it appears that hydrothermal fluids altered the scheelite along crystal edges. Scheelite IIb is found in the slate and sandstone of the Banxi Group proximal to intrusions.

Scheelite III samples are from the quartz-scheelite veins in slate of the Banxi Group distal to the intrusions. Scheelite III crystals are anhedral to sub-euhedral and occur as disseminated individual grains in quartz veins (Figure 4D). It has a typical dark blue CL response (Figure 5D). 


\subsection{Trace Element Compositon of Scheelite}

\subsubsection{Trace Element Characteristics of Scheelite}

The most abundant elements in scheelite from the Chuankou $\mathrm{W}$ deposit are $\mathrm{Mn}, \mathrm{Sr}, \mathrm{Zr}, \mathrm{Nb}, \mathrm{Mo}$, $\mathrm{Sn}, \mathrm{REEs}, \mathrm{Ta}, \mathrm{Pb}, \mathrm{Bi}$, Th and U (Table S1). The trace elements exhibit wide variation between different generations with certain elements ranging over several orders of magnitude, but they are relatively homogenous within one category (Figure 6).
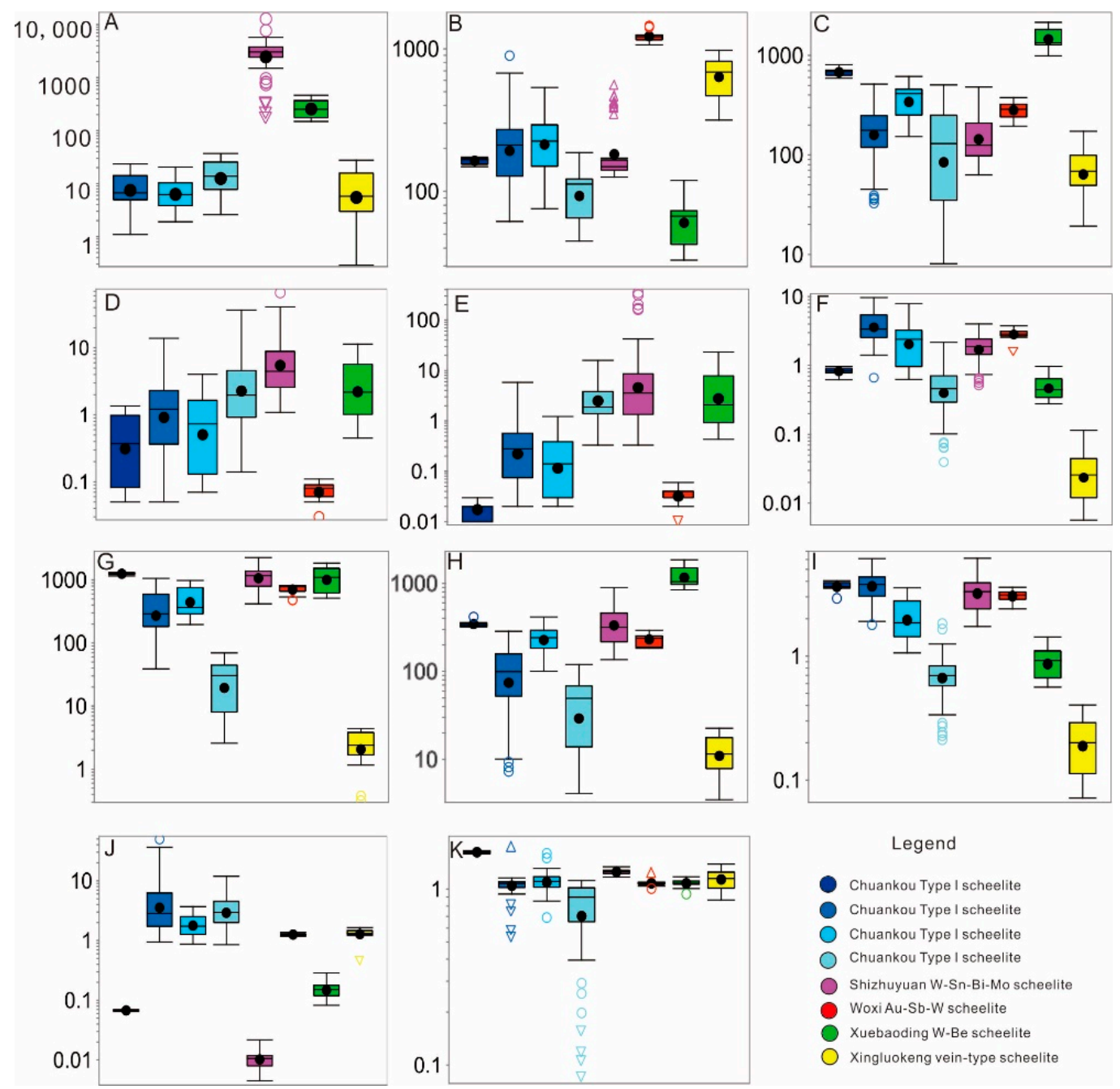

Figure 6. Box plot for trace element (A) Mo; (B) Sr; (C) Y; (D) Th; (E) U; (F) $\mathrm{La}_{\mathrm{N}} / \mathrm{Yb}_{\mathrm{N}}$; (G) LREE; (H) HREE; (I) LREE/HREE; (J) $\delta E u$; (K) $\delta$ Ce in Scheelite from the Chuankou deposit and other related deposits.

In order to better identify the major controls on the origin of the scheelite and its ore-forming mechanisms, we choose some representative scheelite deposits in South China, such as the Xingluokeng quartz-vein type tungsten deposit, Xuebaoding pegmatite W-Sn-Be deposit, Shizhuyuan skarn W-Sn-Bi-Mo deposit and Woxi quartz-scheelite vein Au-Sb-W deposit, for comparison in this study. As shown in Figures 7 and 8, there are significant differences between different types of deposits and different generations of scheelite in the Chuankou tungsten deposit. The detailed summary is as follows: 

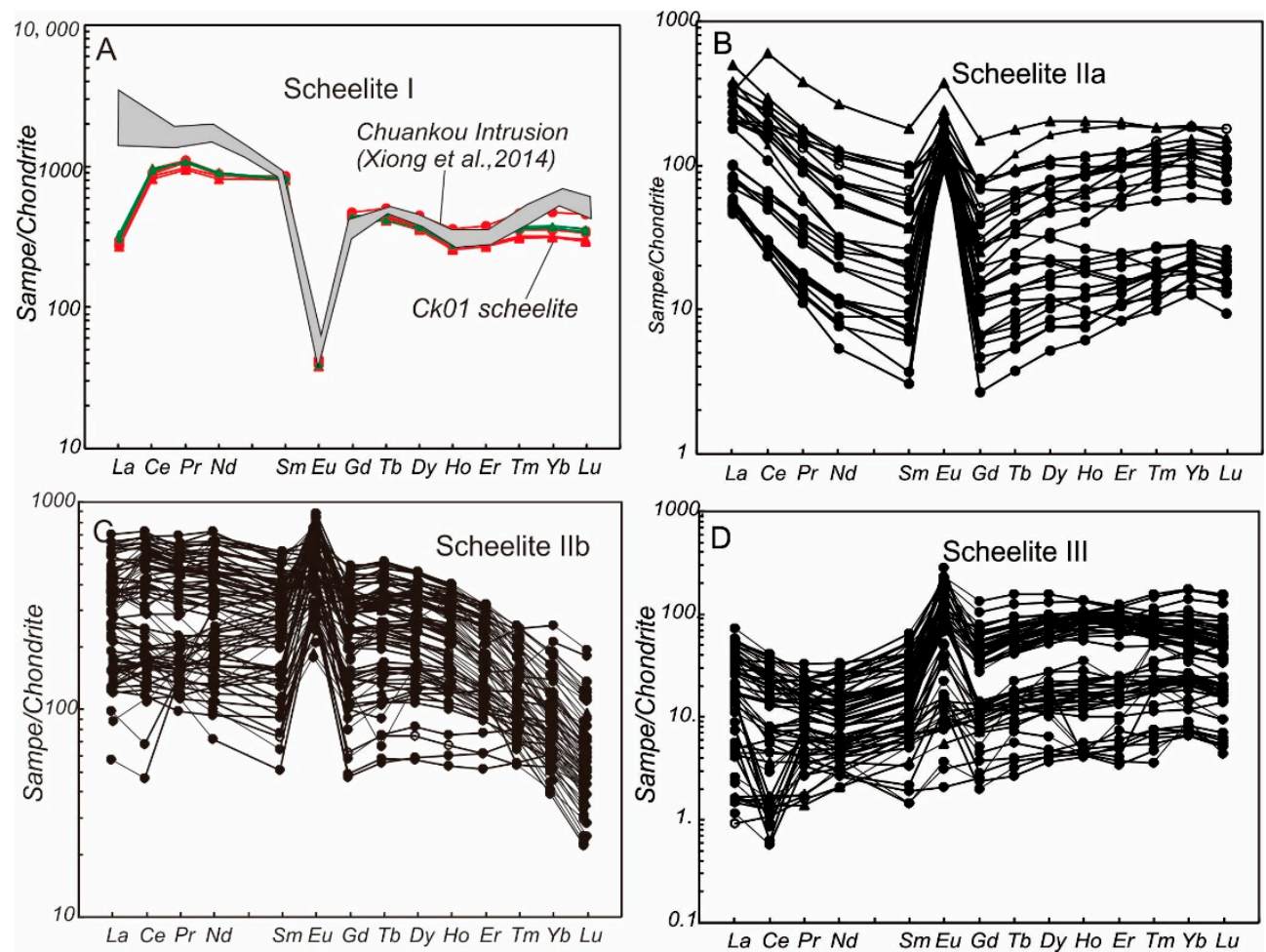

Figure 7. Chondrite-normalized REE patters of different types of scheelites from the Chuankou tungsten deposit. (A) scheelite from the top of the Chuankou intrusion; (B) scheelite from sandstone; (C) scheelite from the boundary between sandstone and slate; (D) scheelite from slate. Chondrite values are from Sun and McDonough [39].
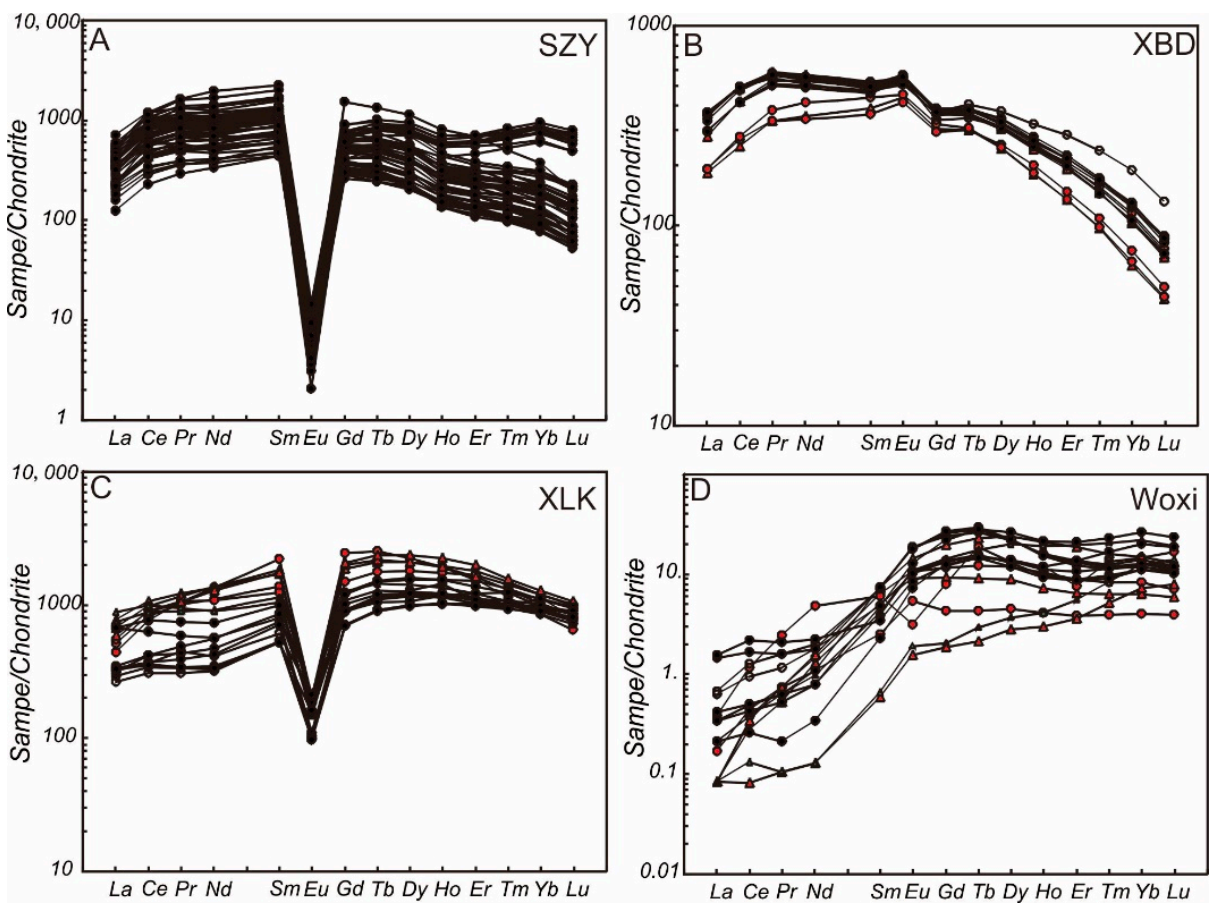

Figure 8. Chondrite-normalized REE patters of scheelites from (A) the Shizhuyuan W-Sn-Bi-Mo deposit, (B) the Xuebaoding W-Sn-Be deposit, (C) the Xingluokeng tungsten deposit and (D) the Woxi $\mathrm{Au}-\mathrm{Sb}$-tungsten deposit. Chondrite values are from Sun and McDonough [39].

All kinds of scheelite have different trace element concentrations in this study. As shown in Figure 6 and Table S1, the variation of Mo ranges from 0.29 to 12,850 ppm with an average $652 \mathrm{ppm}$. 
Mo is rich in the scheelite from the Shizhuyuan W-Sn-Bi-Mo deposit (more than several thousand ppm), then next to Xingluokeng quartz-scheelite deposit (e.g., Figure 6A). Molybdenum are relatively lower in the scheelite from the Chuankou tungsten deposit. Particularly, Mo in Scheelite I is below a detectable limit, which is similar with the Woxi Au-Sb-W deposit.

Both $\mathrm{Sr}$ and $\mathrm{Y}$ have a wide range of 32.9 1450, 8.10 2148 ppm, respectively, in all the samples (e.g., Figure 6B,C). Strontium is highest in the scheelite from the Xuebaoding W-Sn-Be deposit (316 975 ppm, average.665 ppm), and $\mathrm{Y}$ is highest in the scheelite from the Xingluokeng deposit (989 2148 ppm, average $1486 \mathrm{ppm}$ ). Thorium and $\mathrm{U}$ are below 10ppm in most of the samples (e.g., Figure $6 \mathrm{D}, \mathrm{E})$. The $(\mathrm{La} / \mathrm{Yb})_{\mathrm{N}}$ ratio is around 1 except for the scheelite from the Woxi Au-Sb-W deposit (below 0.1) (Figure 6G,H). Heavy rare earth element (HREE) and LREE have large variation of $3.49 \sim 1850 \mathrm{ppm}$ with an average $239 \mathrm{ppm}, 0.32 \sim 2262 \mathrm{ppm}$ with an average $526 \mathrm{ppm}$, respectively. LREE/HREE is below 1 in the scheelite from Scheelite III in Chuankou, Woxi and Xingluokeng (e.g., Figure 6I). $\delta$ Eu values in the scheelite from the Chuankou deposit have a wider range than other tungsten deposit in this study. $\delta$ Ce values in the scheelite III from the Chuankou deposit have a large variation and are lower than those in other deposit (around 1) (Figure 6J,K).

\subsubsection{REE Patterns of Scheelite}

There are many obvious differences between the patterns for scheelite within the Chuankou tungsten deposit (Figure 7). Scheelite I shows LREE-rich patterns, except for element La with a remarkable negative Eu anomaly (Figure 7A). Scheelite IIa shows "W" shape patterns, i.e., LREE-rich, HREE-moderate and MREE-depletion with a positive Eu anomaly (Figure 7B). Scheelite Ilb shows both LREE- and MREE-rich but HREE-depletion with a positive Eu anomaly (Figure 7C). Scheelites III shows LREE-depletion patterns with a positive Eu anomaly (Figure 7D). It is notable that the REE concentrations in scheelite III are significantly lower than other scheelites at Chuankou.

Among the different W-bearing deposits, scheelite from both the Shizhuyuan skarn-type W-Sn-Bi-Mo deposit and the Xingluokeng quartz-vein type tungsten deposit have similarities in REE patterns and REE contents, showing " $\mathrm{M}$ " shape patterns with remarkable negative Eu anomalies (Figure 8A,C). Scheelites from the Xuebaoding pegmatite-type W-Sn-Be deposit show LREE-rich and HREE-depletion patterns with a weak positive Eu anomaly (Figure 8B). HREEs in the Xuebaoding scheelite are highly fractionated [34]. Scheelites from the Woxi Au-Sb-W deposit have very low REE contents and are characterized by LREE-depletion and HREE-enrichment (Figure 8D).

\section{Discussion}

\subsection{Substitution of Trace Elements into Scheelite}

Different valence ions have variable characteristics and substitution mechanisms during the entry into the scheelite lattice $[3,6,15,40]$. Divalent ions such as $\mathrm{Sr}^{2+}, \mathrm{Fe}^{2+}, \mathrm{Mn}^{2+}$ and $\mathrm{Mo}^{2+}$ have the same valence stage and similar radius as $\mathrm{Ca}^{2+}$ in scheelite and can be directly substitute for each other in scheelite [2-6,11]. The 5-valent ions such as $\mathrm{Ta}^{5+}, \mathrm{Nb}^{5+}, \mathrm{V}^{5+}$ and $\mathrm{Mo}^{6+}$ ions can replace $\mathrm{W}^{6+}$ in scheelite, and 6-valent ions can enter directly through isomorphism, and even form a relatively complete series of solid solution minerals, until cooling is sufficient for the formation of the final W-Mo deposit.

The trivalent ions such as $\mathrm{REE}^{3+}$ entering into scheelite lattice are most common, and $\mathrm{REE}^{3+}$ is generally substitute for $\mathrm{Ca}^{2+}$ in the three forms as follows [1,3,6]: (1) $2 \mathrm{Ca}^{2+}=\mathrm{REE}^{3+}+\mathrm{Na}^{+}$, which requires $\mathrm{Na}^{+}$in a solution and the proper REE radius; (2) $\mathrm{Ca}^{2+}+\mathrm{W}^{6+}=\mathrm{REE}^{3+}+\mathrm{Nb}^{5+}$, which is involved in the replacement of trivalent and pentavalent ions in the solution; (3) $3 \mathrm{Ca}^{2+}=2 \mathrm{REE}^{3+}+$ $\square\left(\mathrm{Ca}^{2+}\right.$ vacancy, which requires the same combined valence rather than the ion radius. Furthermore, both $\mathrm{Nb}$ and Ta can be found in the samples. $\mathrm{Nb}^{5+}$ is relatively abundant in all the samples, but $\mathrm{Ta}^{5+}$ is only found in part of the samples. As shown in Figure 9, a positive correlative occurs between the $\Sigma$ REE-Eu $+\mathrm{Y}$ and $\mathrm{Nb}+\mathrm{Ta}$ in scheelite from most of the tungsten deposit of middle to high-temperature system except for the scheelite from the Woxi Au-Sb-W deposit and part of scheelite III from the 
Chuankou tungsten deposit. This indicates that Equation (2) might be an important substitution mechanism in tungsten deposits of a middle to high-temperature mineralization system.

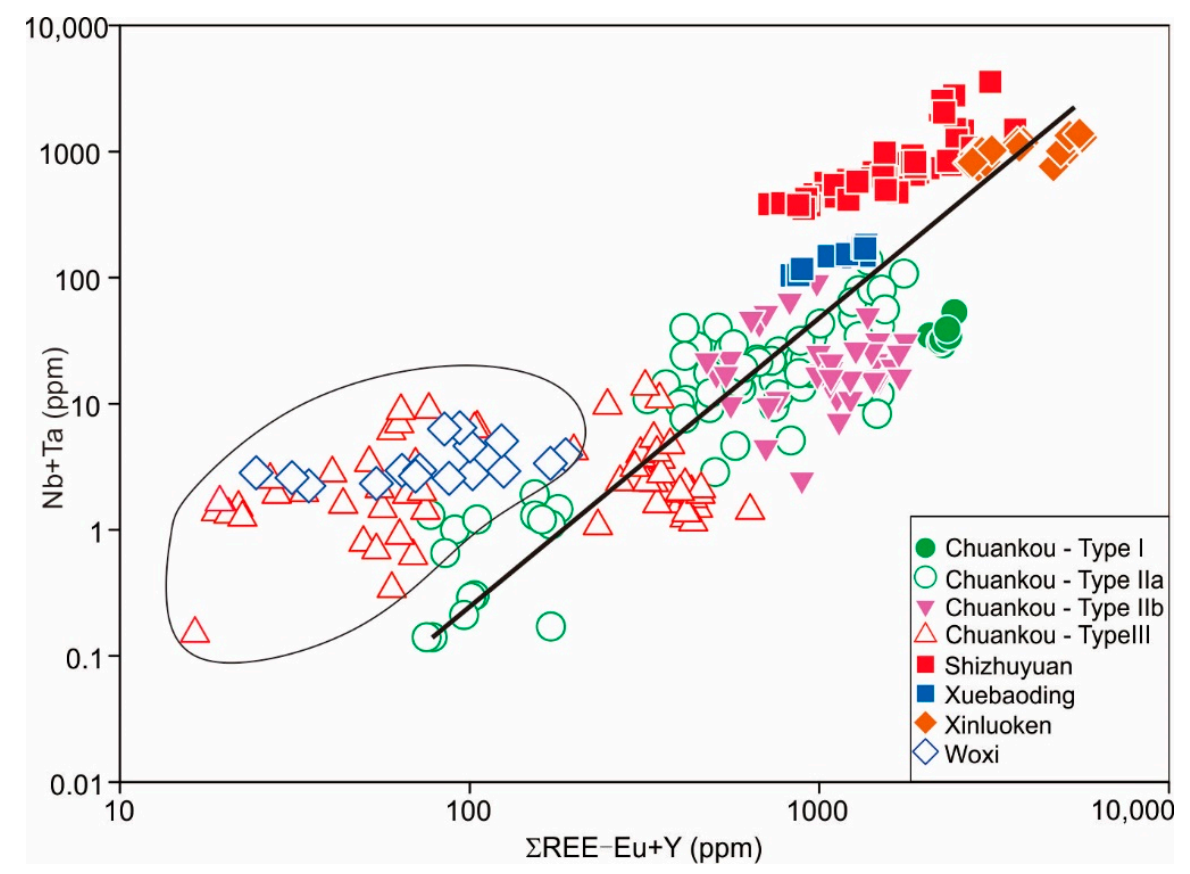

Figure 9. Bivariate diagrams of $\Sigma \mathrm{REE}-\mathrm{Eu}+\mathrm{Y} \mathrm{Vs} \mathrm{Nb}+\mathrm{Ta}$ of scheelite from the Chuankou tungsten deposit and other deposits for comparison (e.g., Shizhuyuan; Xuebaoding; Xingluokeng; and Woxi). Chondrite values are from Sun and McDonough [39].

REE patterns can also indicate the mechanism of substitution [6,12,41]. For example, LREE-rich minerals suggest the main substitution in scheelite is Equation (3), which is not limited by the lattice position and size. REEs $^{3+}$ have similar partition coefficients between scheelite and ore-forming fluids so that and REE composition of scheelite can be used to investigate the REE concentrations in ore-forming fluids. Such REE patterns appear in scheelite IIa and scheelite IIb in the Chuankou tungsten deposit (Figure 7B,C) as well as in the Shizhuyuan W-Sn-Bi-Mo deposit, the Xuebaoding W-Sn-Be deposit, the first generation scheelite from the Dabaoshan poly-metallic deposit and the Zhuxi giant tungsten deposit $[11,15,31,42,43]$, showing that scheelite in these deposit have similar substitution mechanism.

\subsection{Nature, and Evolution of Ore-Forming Fluids}

The nature of ore-forming fluids plays an important role for the precipitation of tungsten minerals. In relatively oxidized fluids, Mo would occur as $\mathrm{Mo}^{6+}$, replacing $\mathrm{W}^{6+}$ by isomorphism. On the contrary, $\mathrm{Mo}^{4+}$ would favor to precipitate as $\mathrm{MoS}_{2}$ under reducing conditions so that Mo contents in ore-forming fluids would decrease during fluid evolution. Therefore, it can be inferred that Mo content in scheelite would be high in the oxidizing environment and be low in a reducing environment $[5,15]$. As shown in Figure 6A, there is an decreasing trend of Mo in scheelite at the Chuankou deposit from Scheelite I to scheelite III, indicating that ore-forming fluids in early stages are likely to be reduced and Mo has been removed from the fluids as molybdenite. Molybdenum in scheelite from the Shizhuyuan skarn W-Sn-Bi-Mo deposit is higher than that of Xingluokeng quartz-wolframite-scheelite vein deposit (Figure 9). Ore-forming fluids of the Shizhuyuan skarn is higher than the fluids of Xingluokeng with the mineral association of wolframite and scheelite, confirming that Mo in scheelite is controlled by oxygen fugacity's of ore-forming fluids.

$\mathrm{Eu}$ anomalies can also be used to evaluate the redox state of ore-forming fluids $[1,6-8,41,44]$. $\mathrm{Eu}$ anomalies of scheelite decreasing from the Shizhuyuan to the Woxi and Type IIb and Type scheelite III in Chuankou deposit vice the Xingluokeng deposit may indicate a decreasing trend of fractionation 
degree. Due to higher partition coefficient of $\mathrm{Eu}^{3+}$, positive Eu anomalies in scheelite indicated high $\mathrm{Eu}^{3+}$ content and high oxygen fugacity of the ore-forming fluids, while negative Eu anomalies generally result from high $\mathrm{Eu}^{2+}$ content with low oxygen fugacity. The relative $\mathrm{Eu}^{3+} / \mathrm{Eu}^{2+}$ ratios of fluids can also be determined according to the relationship between $(\mathrm{Eu})_{\mathrm{N}}$ and $(\mathrm{Eu})_{N^{*}}($ Figures $9 \mathrm{~B}$ and 10$)$. If $(\mathrm{Eu})_{\mathrm{N}}$ and $\mathrm{Eu}^{*}$ have the horizontal trend, the Eu anomalies show the behaviors of $\mathrm{Eu}^{2+}$, indicating the oxygen fugacity of ore-forming fluids was low [6]. According to Figures 9B and 10, scheelite from first stage fluids at the Chuankou deposit plots along the horizontal line, indicative of precipitation from reduced fluids. Alternatively, the other two types of scheelite (scheelite IIa, IIb and scheelite III) from the Chuankou deposit plot along the $(\mathrm{Eu})_{\mathrm{N}} /(\mathrm{Eu})_{N}{ }^{*}=1$ line, suggesting that they have crystallized from relatively oxidized fluids with large variations in of Eu anomalies. The mineral association of molybdenite with scheelite I and magnetite/hematite and scheelite II and III also support evolution history from reduced to oxidized of ore-forming fluids. Therefore, the earlier fluids had negative Eu anomalies and were LREE-rich, which may have been inherited from the magmatic-hydrothermal fluids, whereas the latter fluids with positive Eu anomalies with variable REE components may have involved a different degree of addition of oxidized fluids [34]. Scheelite III has REE patterns similar to the Woxi Au-Sb-W deposit where the fluids may have been thought to be derived from meteoric water [32]. The Xingluokeng scheelite shows a similar horizontal trend with scheelite I of Chuankou, while scheelite of the Woxi and Xuebaoding deposits display the same trend as scheelite II and III of Chuankou, indicative of reduced nature of fluids in Xingluokeng and oxidized feature of the Woxi and Xuebaoding deposits, which are consistent with the oxygen fugacity of ore-forming fluids revealed by Mo contents in scheelite.

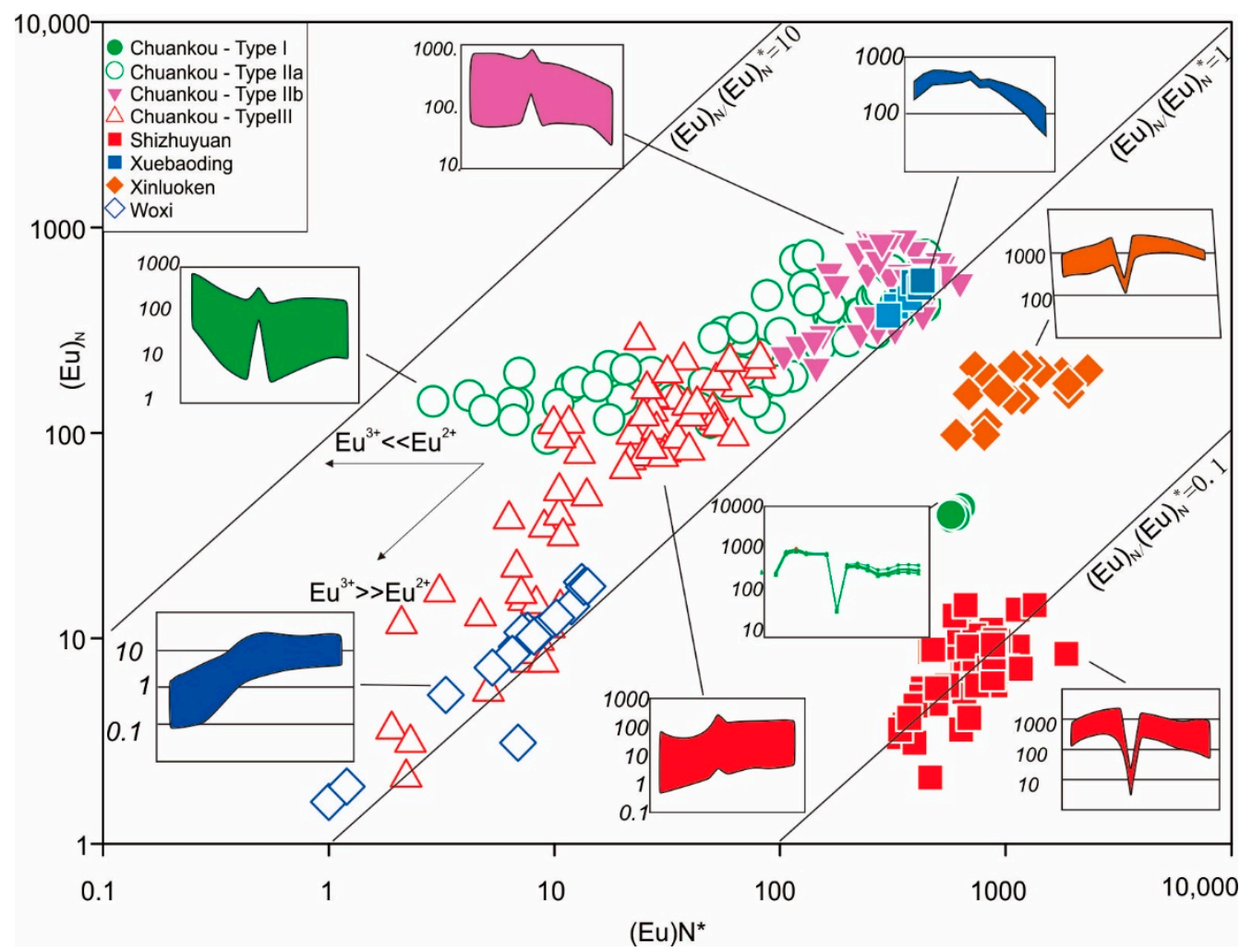

Figure 10. Plot of chondrite-normalized concentrations $(\mathrm{Eu})_{\mathrm{N}}$ versus calculated Eu value $(\mathrm{Eu})_{\mathrm{N}}{ }^{*}$, for scheelites analyzed in this study. Chondrite values are from Sun and McDonough [39].

Strontium is compatible element in scheelite $[8,12]$ so that the precipitation of scheelite will lead to lower Sr content in evolved fluids. Strontium is low in scheelite I, possibly indicating that the early fluids for scheelite I are derived from the highly-fractionated magma. However, Sr is relatively higher in Scheelite IIa and scheelite III from the Chuankou deposit. The larger distance to the granite, the higher 
Sr contents in scheelite. Thus, an extra source of $\mathrm{Sr}$ is required to responsible for the formation of $\mathrm{Sr}$-rich scheelite in later generations. Strontium-rich scheelite is found in the Au-Sb-W deposit in XUB, especially in the Woxi Au-Sb-W deposit, where high $\mathrm{Sr}$ contend fluids have been considered to be the feed of hydrothermal dissolution of the Neoproterozoic stratigraphic sequence $[8,15,30,32]$. The strata in the Chuankou tungsten deposit are Neoproterozoic Banxi group, similar to the country rocks at the Woxi Au-Sb-W deposit [25,30,32]. Slate in the Banxi group can provide extra $\mathrm{Sr}$ in the fluids to formed Sr-rich scheelite. Thus, from scheelite I to Scheelite III, the increasing Sr contents suggest different degrees of the addition of Sr-rich recycled meteoric waters into magmatic fluids.

\subsection{Implications for Tungsten Mineralization}

Hydrothermal tungsten mineralization, as one of the most common and significant mechanisms for the formation of tungsten minerals, is generally believed to be formed by felsic magma-derived fluids or metamorphic hydrothermal fluids $[3,15,21,26,45]$. Ore-forming metals such as tungsten, calcium, manganese and iron are transported and then precipitate at the proper site. Most of the deposits involved in this study are quartz-vein type tungsten deposits, which are located in granite (e.g., the Shizhuyuan W-Sn-Bi-Mo deposit and the Xingluokeng tungsten deposit) or in sedimentary rocks (e.g., the Xuebaoding W-Sn-Be deposit and the Woxi Au-Sb-W deposit). Previous studies of granitic rocks associated with tungsten mineralization in South China have documented that these granitic rocks are rich in tungsten and the compositions and temperature of ore forming fluids could remain similar during the transportation for hundreds of meters $[2,4,6,21,26,31,43]$. The Chuankou tungsten deposit is hosted in both granite and sedimentary rocks. The magmatic hydrothermal fluids are likely to be $\mathrm{W}$-rich and thus can provide great amounts of tungsten. The hydrothermal fluids at the Chuankou tungsten deposit traveled through slate for a long distance from proximal intrusion to distal. During the long-distance transportation, hydrothermal fluids would interact with the surrounding rocks, in particular the slate of the Neoproterozoic Banxi Group and leach Ca and Sr from such strata for the formation of scheelite.

From the results and above discussion, each scheelite from different types show distinct REE patterns and trace elements. Such as low REE and depletion of LREE, low $\mathrm{Nb}+\mathrm{Ta}$ and Mo but Sr-rich is the typical characteristics of the scheelite from low-temperature mineralization system (e.g., Woxi deposit) (Figures 6-9). In contrast, the scheelite from the Xuebaoding W-Sn-Be deposit, the Shizhuyuan W-Sn-Bi-Mo deposit and the Xingluokeng quartz-scheelite vein deposit have typical HREE enrichment and high $\mathrm{Nb}+\mathrm{Ta}$, Mo, typical characteristics of middle to high-temperature mineralization system. Scheelite from the Chuankou deposit have both features due to the addition of meteoric water to change the temperature of ore-forming fluids from high-temperature to low-temperature.

MREE depletion and $\mathrm{Eu}$ anomaly changes are strong evidence of systematical fraction crystallization in the closed system [7,46], such as the scheelite from the Shizhuyuan W-Sn-Bi-Mo deposit. Scheelite I and IIa have such features, indicating that the ore-forming fluids evolve in a close system. Scheelite IIb and scheelite III display similar MREE-rich patterns and relatively low variations of Eu anomalies, which in turn suggest the evolution of ore-forming fluids in an open system. With the opening of fracture system, magma-derived ore-forming fluids mix with recycled meteoric water and become relatively oxidized, precipitating scheelite IIb and scheelite III.

\section{Conclusions}

Based on discussion above, we draw conclusions as follows:

(1) Three generations of scheelite were identified at the Chuankou tungsten deposit.

(2) Two major substitution mechanism occur in scheelite in the Chuankou deposit: $3 \mathrm{Ca}^{2+}=2 \mathrm{REE}^{3+}$ $+\square\left(\mathrm{Ca}^{2+}\right.$ vacancy $)$ and $\mathrm{Ca}^{2+}+\mathrm{W}^{6+}=\mathrm{REE}^{3+}+\mathrm{Nb}^{5+}$, suggesting a middle to high-temperature mineralization system. 
(3) REE contents and patterns indicate that two types of fluids were involved in the ore-forming system. The early fluids were derived from the reduced and highly evolved magma. The fluids mixed with oxidizing meteoric water during the opening of fracture system to form later scheelite generations.

Supplementary Materials: The following are available online at http://www.mdpi.com/2075-163X/10/11/1007/s1, Table S1: LA ICPMS Trace element concentrations of scheelites from the Chuankou tungsten deposit and related deposits in this study.

Author Contributions: Conceptualization, T.D.; Data curation, W.L.; Formal analysis, T.D. and R.C.B.; Funding acquisition, J.G. and D.Z.; Investigation, J.P. and W.L.; Methodology, T.D.; Software, D.Z.; Writing一original draft, J.P.; Writing-review and editing, J.P., T.D., J.G., D.Z. and R.C.B. All authors have read and agreed to the published version of the manuscript.

Funding: This research was funded by the National Key R\&D Program of China (2016YFC0600207) and the National Natural Science Foundation of China (Grant No. 41672082).

Acknowledgments: We are grateful to Z.W. Deng and S.P. Tian from the Chuankou Yuanjing tungsten mine for theirs support during the field work and sample collecting. The manuscript greatly benefited from comments from the Journal reviewers.

Conflicts of Interest: The authors declare no conflict of interest.

\section{References}

1. Brugger, J.; Maas, R.; Lahaye, Y.; McRae, C.; Ghaderi, M.; Costa, S.; Lambert, D.; Bateman, R.; Prince, K. Origins of $\mathrm{Nd}-\mathrm{Sr}-\mathrm{Pb}$ isotopic variations in single scheelite grains from Archaean gold deposits, Western Australia. Chem. Geol. 2002, 182, 203-225. [CrossRef]

2. Ding, T.; Ma, D.; Lu, J.; Zhang, R. Garnet and scheelite as indicators of multi-stage tungsten mineralization in the Huangshaping deposit, southern Hunan province, China. Ore Geol. Rev. 2018, 94, 193-211. [CrossRef]

3. Dostal, J.; Kontak, D.J.; Chatterjee, A.K. Trace element geochemistry of scheelite and rutile from metaturbidite-hosted quartz vein gold deposits, Meguma Terrane, Nova Scotia, Canada: Genetic implications. Miner. Pet. 2009, 97, 95-109. [CrossRef]

4. Fu, Y.; Hollings, P.; Zhou, H.; Lin, H.; Jiang, L.; Yang, T. In-situ LA-ICP-MS trace elements analysis of scheelites from the giant Beiya gold-polymetallic deposit in Yunnan Province, Southwest China and its metallogenic implications. Ore Geol. Rev. 2017, 80, 828-837. [CrossRef]

5. Poulin, R.S. A Study of the Crystal Chemistry, Cathodoluminescene, Geochemistry and Oxygen Isotopes in Scheelite: Application towards Discriminating among Differing Ore-Deposit Systems. Ph.D. Thesis, Laurentian University, Sudbury, ON, Canada, 2016.

6. Ghaderi, M.; Palin, J.M.; Campbell, I.H.; Sylvester, P.J. Rare earth element systematics in scheelite from hydrothermal gold deposits in the Kalgoorlie-Norseman region, Western Australia. Econ. Geol. 1999, 94, 423-437. [CrossRef]

7. Choi, W.; Park, C.; Song, Y. Multistage W-mineralization and magmatic-hydrothermal fluid evolution: Microtextural and geochemical footprints in scheelite from the Weondong W-skarn deposit, South Korea. Ore Geol. Rev. 2020, 116, 103219. [CrossRef]

8. Li, X.-Y.; Gao, J.-F.; Zhang, R.-Q.; Lu, J.-J.; Chen, W.-H.; Wu, J.-W. Origin of the Muguayuan veinlet-disseminated tungsten deposit, South China: Constraints from in-situ trace element analyses of scheelite. Ore Geol. Rev. 2018, 99, 180-194. [CrossRef]

9. Xu, D.; Deng, T.; Chi, G.; Wang, Z.; Zou, F.; Zhang, J.; Zou, S. Gold mineralization in the Jiangnan Orogenic Belt of South China: Geological, geochemical and geochronological characteristics, ore deposit-type and geodynamic setting. Ore Geol. Rev. 2017, 88, 565-618. [CrossRef]

10. Yang, J.-H.; Kang, L.-F.; Liu, L.; Peng, J.-T.; Qi, Y.-Q. Tracing the origin of ore-forming fluids in the Piaotang tungsten deposit, South China: Constraints from in-situ analyses of wolframite and individual fluid inclusion. Ore Geol. Rev. 2019, 111, 102939. [CrossRef]

11. Yuan, L.; Chi, G.; Wang, M.; Li, Z.; Xu, D.; Deng, T.; Geng, J.; Hu, M.; Zhang, L. Characteristics of REEs and trace elements in scheelite from the Zhuxi W deposit, South China: Implications for the ore-forming conditions and processes. Ore Geol. Rev. 2019, 109, 585-597. [CrossRef] 
12. Brugger, J.; Etschmann, B.; Pownceby, M.; Liu, W.; Grundler, P.; Brewe, D. Oxidation state of europium in scheelite: Tracking fluid-rock interaction in gold deposits. Chem. Geol. 2008, 257, 26-33. [CrossRef]

13. Guo, S.; Chen, Y.; Liu, C.-Z.; Wang, J.-G.; Su, B.; Gao, Y.-J.; Wu, F.-Y.; Sein, K.; Yang, Y.-H.; Mao, Q. Scheelite and coexisting F-rich zoned garnet, vesuvianite, fluorite, and apatite in calc-silicate rocks from the Mogok metamorphic belt, Myanmar: Implications for metasomatism in marble and the role of halogens in $\mathrm{W}$ mobilization and mineralization. J. Asian Earth Sci. 2016, 117, 82-106. [CrossRef]

14. Zhang, Q.; Zhang, R.-Q.; Gao, J.-F.; Lu, J.-J.; Wu, J.-W. In-situ LA-ICP-MS trace element analyses of scheelite and wolframite: Constraints on the genesis of veinlet-disseminated and vein-type tungsten deposits, South China. Ore Geol. Rev. 2018, 99, 166-179. [CrossRef]

15. Sciuba, M.; Beaudoin, G.; Grzela, D.; Makvandi, S. Trace element composition of scheelite in orogenic gold deposits. Miner. Deposita 2019, 55, 1149-1172. [CrossRef]

16. Gaft, M.; Panczer, G.; Uspensky, E.; Reisfeld, R. Laser-induced time-resolved luminescence of rare-earth elements in scheelite. Miner. Mag. 1999, 63, 199-210. [CrossRef]

17. Poulin, R.S.; McDonald, A.M.; Kontak, D.J.; McClenaghan, M.B. On the Relationship Between Cathodoluminescence and the Chemical Composition of Scheelite From Geologically Diverse Ore-Deposit Environments. Can. Miner. 2016, 54, 1147-1173. [CrossRef]

18. Götze, J.; Schertl, H.-P.; Neuser, R.D.; Kempe, U.; Hanchar, J.M. Optical microscope-cathodoluminescence (OM-CL) imaging as a powerful tool to reveal internal textures of minerals. Miner. Pet. 2012, 107, 373-392. [CrossRef]

19. Raju, P.V.S.; Hart, C.J.; Sangurmath, P. Scheelite geochemical signatures by LA-ICP-MS and potential for rare earth elements from Hutti Gold Mines and fingerprinting ore deposits. J. Afr. Earth Sci. 2016, 114, 220-227. [CrossRef]

20. Sylvester, P.J.; Ghaderi, M. Trace element analysis of scheelite by excimer laser ablation-inductively coupled plasma-mass spectrometry (ELA-ICP-MS) using a synthetic silicate glass standard. Chem. Geol. 1997, 141, 49-65. [CrossRef]

21. Hu, R.-Z.; Chen, W.T.; Xu, D.-R.; Zhou, M.-F. Reviews and new metallogenic models of mineral deposits in South China: An introduction. J. Asian Earth Sci. 2017, 137, 1-8. [CrossRef]

22. USGS. Commodity Statistics and Information. 2020. Available online: https://pubs.usgs.gov/periodicals/ (accessed on 15 April 2020).

23. Shen, J.F.; Chen, Z.H.; Liu, L.J.; Ying, L.J.; Huang, F.; WANG, D.H.; Wang, J.H.; Zeng, L. Outline of Metallogney of Tungsten Deposits in China. Acta Geol. Sin. 2015, 89, 1038-1050.

24. HBGMR. Regional Geology of Hunan Province; Geological Publishing House: Beijing, China, 1988.

25. HBGMR. Exploration Report of Replaceable Resources in the Zhazixi Sb(W) Ore Deposit; Unpublished Report; Changsha, China, 2010; pp. 10-45.

26. Zaw, K.; Peters, S.G.; Cromie, P.; Burrett, C.; Hou, Z. Nature, diversity of deposit types and metallogenic relations of South China. Ore Geol. Rev. 2007, 31, 3-47. [CrossRef]

27. Mao, J.; Zhang, Z.H.; Zhang, Z.C. Large Scale Mineralization and Large Ore Concentration Area; Geologic Publishing House: Beijing, China, 2005.

28. Zeng, G.; Gong, Y.; Wang, Z.; Hu, X.; Xiong, S. Structures of the Zhazixi Sb-W deposit, South China: Implications for ore genesis and mineral exploration. J. Geochem. Explor. 2017, 182, 10-21. [CrossRef]

29. Zeng, G.-P.; Gong, Y.-J.; Hu, X.-L.; Xiong, S.-F. Geology, fluid inclusions, and geochemistry of the Zhazixi $\mathrm{Sb}-\mathrm{W}$ deposit, Hunan, South China. Ore Geol. Rev. 2017, 91, 1025-1039. [CrossRef]

30. Gu, X.; Zhang, Y.; Schulz, O.; Vavtar, F.; Liu, J.; Zheng, M.; Zheng, L. The Woxi W-Sb-Au deposit in Hunan, South China: An example of Late Proterozoic sedimentary exhalative (SEDEX) mineralization. J. Asian Earth Sci. 2012, 57, 54-75. [CrossRef]

31. Liang, Y.; Wang, G.; Liu, S.; Sun, Y.; Huang, Y.; Hoshino, K. A Study on the Mineralization of the Woxi Au-Sb-W Deposit, Western Hunan, China. Resour. Geol. 2014, 65, 27-38. [CrossRef]

32. Peng, J. Scheelite Sm-Nd dating and quartz Ar-Ar dating for Woxi Au-Sb-W deposit, western Hunan. Chin. Sci. Bull. 2003, 48, 2640. [CrossRef]

33. Zhang, J.J.; Chen, Z.H.; Wang, D.H.; Chen, Z.Y.; Liu, S.B.; Wang, C.H. Geological characteristics and metallognenic epoch of the Xingluokeng Tugsten Deposit, Fujian Province. Geotecton. Metallog. 2008, 32, 92-97. 
34. Liu, Y.; Deng, J.; Li, C.; Shi, G.; Zheng, A. REE composition in scheelite and scheelite Sm-Nd dating for the Xuebaoding W-Sn-Be deposit in Sichuan. Chin. Sci. Bull. 2007, 52, 2543-2550. [CrossRef]

35. Zhang, D.; Peng, J.; Coulson, I.M.; Hou, L.; Li, S. Cassiterite U-Pb and muscovite40Ar-39Ar age constraints on the timing of mineralization in the Xuebaoding Sn-W-Be deposit, western China. Ore Geol. Rev. 2014, 62, 315-322. [CrossRef]

36. Zhu, X.; Raschke, M.B.; Liu, Y. Tourmaline as a Recorder of Ore-Forming Processes in the Xuebaoding W-Sn-Be Deposit, Sichuan Province, China: Evidence from the Chemical Composition of Tourmaline. Minerals 2020, 10, 438. [CrossRef]

37. Li, Z. Geological characteristics and targetting of Chuankou W deposit, Hengyan City, China. J. Hunan Univ. Sci. Eng. 2017, 38, 72-75.

38. Griffin, W.L.; Powell, W.J.; Pearson, N.J.; O’Reilly, S.Y. GLITTER: Data reduction software for laser ablation ICP-MS. In Laser Ablation ICP-MS in the Earth Sciences: Current Practices and Outstanding Issues; Short Course Series; Sylvester, P.J., Ed.; Mineralogical Association of Canada: Vancouver, BC, Canada, 2008; Volume 40, pp. 308-311.

39. Sun, S.-S.; McDonough, W.F. Chemical and isotopic systematics of oceanic basalts: Implications for mantle composition and processes. Geol. Soc. Lond. Spec. Publ. 1989, 42, 313-345. [CrossRef]

40. Zhao, W.W.; Zhou, M.-F.; Williams-Jones, A.E.; Zhao, Z. Constraints on the uptake of REE by scheelite in the Baoshan tungsten skarn deposit, South China. Chem. Geol. 2018, 477, 123-136. [CrossRef]

41. Bau, M. Controls on the fractionation of isovalent trace elements in magmatic and aqueous systems: Evidence from $\mathrm{Y} / \mathrm{Ho}, \mathrm{Zr} / \mathrm{Hf}$, and lanthanide tetrad effect. Contrib. Miner. Pet. 1996, 123, 323-333. [CrossRef]

42. Mao, W.; Rusk, B.; Yang, F.; Zhang, M. Physical and Chemical Evolution of the Dabaoshan Porphyry Mo Deposit, South China: Insights from Fluid Inclusions, Cathodoluminescence, and Trace Elements in Quartz. Econ. Geol. 2017, 112, 889-918. [CrossRef]

43. Chen, G.; Gao, J.; Lu, J.; Zhang, R. In situ LA-ICP-MS analyses of mica and wolframite from the Maoping tungsten deposit, southern Jiangxi, China. Acta Geochim. 2020, 39, 811-829. [CrossRef]

44. Raimbault, L.; Baumer, A.; Dubru, M.; Benkerrou, C.; Zahm, A. Ree Fractionation between Scheelite and Apatite in Hydrothermal Conditions. Am. Mineral. 1993, 78, 1275-1285.

45. Chowdhury, S.; Lentz, D.R. Mineralogical and geochemical characteristics of scheelite-bearing skarns, and genetic relations between skarn mineralization and petrogenesis of the associated granitoid pluton at Sargipali, Sundergarh District, Eastern India. J. Geochem. Explor. 2011, 108, 39-61. [CrossRef]

46. Cao, J.; Yang, X.; Zhang, D.; Yan, F. In situ trace elements and Sr isotopes in scheelite and S-Pb isotopes in sulfides from the Shiweidong W-Cu deposit, giant Dahutang ore field: Implications to the fluid evolution and ore genesis. Ore Geol. Rev. 2020, 125, 103696. [CrossRef]

Publisher's Note: MDPI stays neutral with regard to jurisdictional claims in published maps and institutional affiliations.

(C) 2020 by the authors. Licensee MDPI, Basel, Switzerland. This article is an open access article distributed under the terms and conditions of the Creative Commons Attribution (CC BY) license (http://creativecommons.org/licenses/by/4.0/). 